Ethiopian Journal of Environmental Studies \& Management 10(3): 276 - 285, 2017.

ISSN:1998-0507

doi: https://dx.doi.org/10.4314/ejesm.v10i3.1

Submitted: November 21, 2016

Accepted: April 03, 2017

\title{
AGRICULTURAL INFORMATION SYSTEMS AND COMMUNICATION NETWORKS: THE CASE OF POULTRY FARMERS IN THE FEDERAL CAPITAL TERRITORY ABUJA, NIGERIA
}

\author{
TSADO, J.H., AJAYI, O.J., FATOKI, P., MOHAMMED, H.U. AND MERCY, 0. \\ Department of Agricultural Economics and Extension Technology, Federal University of \\ Technology Minna, Nigeria
}

\begin{abstract}
The study examined the Agricultural Information and communication networks among poultry farmers in three (3) area councils of the Federal Capital Territory Abuja, Nigeria. Snow-ball sampling technique was adopted for the study, a total of One hundred and twenty-two (122) respondents were sampled for the study. The main objective was to examine the communication sources and networking available to poultry farmers. Descriptive statistics and inferential statistics were used to analyze the data collected. The study revealed that majority (60\%) of the respondents were still in their productive age, male were the majority (81.1\%), while $79.3 \%$ had one form of education or the other. The study also showed that majority of the respondents (71.3\%) had between 901-1100 birds and $56.2 \%$ sold their birds directly to the consumers. The study showed that information disseminated via extension agents, radio, poultry farmers associations and feed millers were found to be effective means of networking among poultry farmers. Out of the thirteen independent variables under consideration: Age, Gender, Household size, Educational level, Years of experience, Access to credit, Access to training, Membership of co-operations and access to communication networks were found to be statistically significant and influence the frequency of access to information. All the constraints under consideration affecting access to information were found to be serious constraints in exception of poor market structures and poor transportation. The study concludes that socio-economic and institutional variables significantly and positively influence poultry farmer's access to information and communication networks.
\end{abstract}

Key Words: Information system, Communication, Network, Poultry farmers

\section{Introduction}

Communication of information is said to be the process by which people exchange ideas, feelings or impression so that each gains a common understanding of the meaning and intent of the massage. Information channels/systems used by farmers are mass media that include radio, television and newspaper, contact with extension staffs or workers and with other farmers (Olaniyi, 2013; Alder and Bagnol, 2000; Ofuoku, 2010).

Livestock production constitutes an important component of the agricultural

*Corresponding Author: Tsado, J.H.

Email: jacobtsado2007@yahoo.com

\section{6}


economy in developing countries like Nigeria. In livestock production, poultry dominates a prominent position in providing animal protein as it accounts for $25 \%$ of local meat production in Nigeria (Okunlola and Olofinsawe, 2007; Gueye, 2000; Branckaert, 2000).

Information and communication technology (ICT) is a broad subject which deals with technology and other aspects of managing and processing information, especially in large organizations. It can be considered a subdiscipline of computer. Particularly IT (information technology) is applied and employs the use of electronic computers, storage media, network administration, server maintenance and computer software to secure, convert, store, protect, process, transmit, and retrieve information (Waltham, 1999; Salau and Saingbe 2008; Adams, 1982).

The information or idea is the subject matter that the farmers are expected to get, understand and act upon; the language of the message, it's idea or contents and the presentation of the information to the farmer matters (Okoedo-Okojie and Orhiakhi, 2012). Adekunle and Ogoto (1994) maintained that effective communication is a precondition for sustainable technology transfer in agriculture; and the forwardfeed- back mechanisms which are essential ingredients in the technology transfer process are only made possible through communication process. Poultry production has a very important impact on our nation's economy. The findings of Okonkwo and Akubuo (2001) revealed that about 10 percent of the Nigerian populations are engaged in poultry production, most on subsistence and small or medium-sized farms, the authors further stressed that presently the industry had been seriously affected by government economy measures. The measure had been very pronounced on poultry production due to high level of sensitivity of the livestock industry to management factor and resultant effect on live and productivity of the birds.

Poultry farmers receive new ideas or improved technology via many sources, some of these sources among others includes through extension agents, mass Medias, opinion leaders, etc. The sharing of these new ideas is being influenced by many factors like types of relevant information being brought to poultry farmers, and their socio-economic status, these may positively or negatively affect their access to information.

The broad objective of the study was to determine the factors influencing access to agricultural information system and communication networks among poultry farmers in Federal Capital Territory Abuja. The specific objective includes to:

- describe the socio-economic characteristics of poultry farmers in the study area,

- examine the communication sources and channels available to poultry farmers in the study area

- determine poultry farmers perception of the communication sources and channels

- determine factors influencing poultry farmers access to information and

- examine the constraints faced by poultry farmer's and their perception of the constraints. 


\section{Methodology}

The study was conducted in the Federal Capital Territory (FCT), Abuja. FCT has 6 area councils; it is located in the guinea savannah which is favorable for poultry production. Few indigenes engaged in farming, white-collar jobs, and Artisan activities such as tailoring, carpentering, blacksmith, mechanics, electricians and other pithy trades.

The study covered three (3) area councils of the Federal Capital Territory, The three area councils randomly selected were Abuja Municipal, Bwari, and Kuje. The sampling frames for each of the extension blocks and cells were not readily available, as a result snow-ball sampling technique was adopted and with help of the community leaders and extension agents a total of one hundred and twenty-two (122) functional poultry farms were sampled for the study.

The data for the study were collected through the administration of questionnaire. Both descriptive and inferential statistics were used for data analysis, the descriptive statistics used include: frequency counts, percentages and means, multiple regression analysis was used to determine the factors affecting poultry farmer's access to information

\section{Multiple Regressions}

The Functional forms or Implicit Forms

\section{Simple Linear Form}

$\mathrm{Y}=\beta_{0}+\beta_{1} \mathrm{X}_{1}+\beta_{2} \mathrm{X}_{2}+\beta_{3} \mathrm{X}_{3}+$

Semi-Logarithm Form

$\mathrm{Y}=\log \beta_{0}+\beta_{1} \log \mathrm{X}_{1}+\beta_{2} \log \mathrm{X}_{2}+\beta_{3} \log \mathrm{X}_{3}+$

$\beta_{\mathrm{n}} X_{\mathrm{n}}+\mathrm{U}$

Double-Logarithm Form

$\log Y=\beta_{0}+\beta_{1} X_{1}+\beta_{2} X_{2}+\beta_{3} X_{3}+$

\section{Exponential Form}

$\log Y=\log \beta_{0}+\beta_{1} \log X_{1}+\beta_{2} \log X_{2}+\beta_{3} \log X_{3}+$ $\beta_{n} \log X_{n}+U$

$$
\beta_{n} X_{n}+U
$$

The Explicit Forms where;

$\mathrm{Y}=$ Frequency of access to information (Dependent variable)

(Independent variables)

$\mathrm{X}_{1}=$ Age

$\mathrm{X}_{2}=$ Gender

$\mathrm{X}_{3}=$ House-hold size

$\mathrm{X}_{4}=$ Educational level

$\mathrm{X}_{5}=$ Years of experience

$\mathrm{X}_{6}=$ Extension services

$\mathrm{X}_{7}=$ Sources of credits/loan

$\mathrm{X}_{8}=$ Sources of extension contact

$\mathrm{X}_{9}=$ Access to credit

$\mathrm{X}_{10}=$ Access to training

$\mathrm{X}_{11}=$ Perception of communication network

$\mathrm{X}_{12}=$ Membership of cooperative society

$\mathrm{X}_{13}=$ Access to communication facilities 
$\beta=$ is the vector of parameters to be estimated

$\mathrm{X}=$ The explanatory variables

$\mathrm{U}=$ Error term

\section{Results and Discussion}

Table 1 showed that a greater proportion of the respondents (90.9\%) were within the active age range of 31-50 years, while only $3.3 \%$ were above 50 years. This implies that majority of the respondents are still in their active and productive age, this result is in line with that of Agwu and Chah (2007) who pointed out that most of their respondents were in their middle age of between 46-

50 years. Table 1 also indicated that male $(81.1 \%)$ dominated the industry in the study area, while $100 \%$ of the respondents in the industry had one form of education or the other, with majority having up to secondary education. this implies that literacy level among the poultry farmers is quite high, this is in agreement with the founding's of Adisa and Akinkunmi (2012) who pointed out that most of their respondents involved in the industry were highly educated.

Table 1: Distribution of Respondents According to their Socio-Economic Characteristics

\begin{tabular}{lll}
\hline Socio economic variables & Frequency & Percentage \\
\hline Age & 7 & 5.7 \\
$21-30$ & 73 & 59.8 \\
$31-40$ & 38 & 31.1 \\
$41-50$ & 4 & 3.3 \\
51 and above & & \\
Sex & 99 & 81.1 \\
Male & 23 & 18.9 \\
Female & & \\
Level of Education & 11 & 9.0 \\
Primary & 87 & 71.3 \\
Secondary & 24 & 19.7 \\
Tertiary & & \\
Types of Birds kept & 50 & 41.0 \\
Layers only & 51 & 41.8 \\
Broilers only & 2 & 1.6 \\
Cockerel only & 13 & 10.7 \\
Layers / broilers & 6 & 4.9 \\
Layers / broilers / cockerel & & \\
Number of Birds Owned & 15 & 12.3 \\
Less than 4000 & 19 & 15.6 \\
501 - 700 & 8 & 6.6 \\
$701-900$ & 36 & 29.5 \\
$901-1,100$ & 30 & 24.6 \\
$1101-1,300$ & 14 & 11.4 \\
Over1,300 & 81 & 66.4 \\
Access to Agricultural Information & 279 & \\
Frequently & & \\
& &
\end{tabular}


Occasionally

Rarely

Year of poultry farming experience

Less than 5 years

5-10years

11-15years

Above 15 years
41

20

36

16

50
33.6

16.4

29.5

13.1

41.0
Also Table 1 revealed that $41.8 \%$ and $41.0 \%$ of the respondents reared only broilers and layers respectively. This may not be unconnected with the fact that in FCT majority of the inhabitants are medium income earners who could afford to buy both meat and eggs for their household. This result is however, in disagreement with that of Adisa and Akinkunmi (2012), who claimed that most of their respondents reared layers only. Majority of the respondents (54.1\%) reared between 901-1,300 birds and only $11.4 \%$ reared above 1,300 birds. This implies that most of the respondents involved in the industry in the study area are small -to -medium scale producers, while larger proportion $(66.4 \%)$ claimed that they had access to frequent information, this may not be unconnected with the high literacy level of the respondents and other personal characteristics. This agrees with the findings of Röling and Engel (1991), who find that personal characteristics and the husbandry practices of the farmers were major factors influencing their search and access to information from different sources.

Tables 2 showed that $34.4 \%$ of the respondents received major information on medical/diseases which ranked $1^{\text {st }}$, as this is one of the major challenges to poultry farmers in the Study area; $28.0 \%$ of the poultry farmers received information on hybrid stocks which ranked $2^{\text {nd }}$ while $19.7 \%$ of the farmers obtained major information on feeds and feeding stuff which ranked $3^{\text {rd }}$ this implies that farmers received information on different management aspects depending on their area of interest, priority and the problems they faced.

Table 2: Distribution of Respondents According to Major Type of Management Information Received.

\begin{tabular}{|c|c|c|c|}
\hline $\begin{array}{l}\text { Management information } \\
\text { Rank }\end{array}$ & Frequency & \multicolumn{2}{|c|}{ Percentage } \\
\hline Information on hybrid & 78 & 28.0 & $2^{\text {nd }}$ \\
\hline Information on feeds & 55 & 19.7 & $3^{\text {rd }}$ \\
\hline Information on medical services & 96 & 34.4 & $1^{\text {st }}$ \\
\hline Information on Marketing & 29 & 10.4 & $4^{\text {th }}$ \\
\hline Information on ICT usage/application & 8 & 2.9 & $6^{\text {th }}$ \\
\hline All of the above & 13 & 4.7 & $5^{\text {th }}$ \\
\hline
\end{tabular}


Tables 3: Distribution of respondents according to sources of information and perceived effectiveness of the information systems

\begin{tabular}{|c|c|c|c|c|c|c|c|}
\hline \multicolumn{8}{|c|}{ Perception } \\
\hline $\begin{array}{l}\text { Sources of } \\
\text { Information }\end{array}$ & $\begin{array}{l}\text { Very } \\
\text { Effective }\end{array}$ & Effective & $\begin{array}{l}\text { Fairly } \\
\text { effective }\end{array}$ & $\begin{array}{l}\text { Not } \\
\text { effective }\end{array}$ & Sum & Mean & Remarks \\
\hline Radio & $4(3.3)$ & $110(90.2)$ & $1(0.8)$ & $7(5.7)$ & 355 & 2.9 & Effective \\
\hline Television & $1(0.8)$ & $18(14.8)$ & $9(7.4)$ & $94(77.0)$ & 170 & 1.35 & $\begin{array}{l}\text { Not } \\
\text { Effective }\end{array}$ \\
\hline $\begin{array}{l}\text { Extension } \\
\text { Agents }\end{array}$ & $67(54.9)$ & $28(23.0)$ & $28(23.0)$ & $27(22.1)$ & 435 & 3.56 & Effective \\
\hline Family/Friends & $16(13.1)$ & $18(14.8)$ & $9(7.4)$ & $79(64.8)$ & 215 & 1.76 & $\begin{array}{l}\text { Not } \\
\text { Effective }\end{array}$ \\
\hline Other Farmers & $16(13.1)$ & $19(15.6)$ & $8(6.6)$ & $79(64.8)$ & 216 & 1.77 & $\begin{array}{l}\text { Not } \\
\text { Effective }\end{array}$ \\
\hline $\begin{array}{l}\text { Veterinary } \\
\text { Officers }\end{array}$ & $10(8.2)$ & $25(20.5)$ & $84(68.9)$ & $3(2.5)$ & 286 & 2.34 & Effective \\
\hline $\begin{array}{l}\text { Poultry } \\
\text { Association }\end{array}$ & - & $89(73.7)$ & $5(4.1)$ & $28(23.0)$ & 305 & 2.50 & Effective \\
\hline
\end{tabular}

*Figures in parenthesis are percentages

Table 3 showed that information disseminated via extension agents, radio, poultry associations and feed millers were found to be effective. While information disseminated via television, family/friends and other farmers were not perceived as effective by the poultry farmers in the study areas, such they are rarely used as source of information, Hence information to poultry farmers should always be channeled through the information sources perceived by them as important and effective. This is consistent with the findings of FAO (2000), who pointed out that mass media help the extension agents to reach large number of farmers simultaneously, since there was little opportunity for the farmers to interact among themselves. 
Agricultural Information Systems and Communication Networks.................TSADO et al.

Table 4: Factors affecting Poultry Farmer's access to Agricultural Information and Networking

\begin{tabular}{|c|c|c|c|c|}
\hline Variables & Linear & Semi-log & Double-log & Exponential \\
\hline Constants & $\begin{array}{l}29985.008 \\
(14.756)\end{array}$ & $\begin{array}{l}11.523 \\
(84.597)\end{array}$ & $\begin{array}{l}5.019 \\
(6.292)\end{array}$ & $\begin{array}{l}-1849975.201 \\
(-6.765)\end{array}$ \\
\hline Age & $\begin{array}{l}11.933 \\
(2.669)^{* * *}\end{array}$ & $\begin{array}{l}\text { 7.657E-6 } \\
(3.887)^{* * *}\end{array}$ & $\begin{array}{l}0.166 \\
(3.262)\end{array}$ & $\begin{array}{l}38828.113 \\
(2.229)^{* *}\end{array}$ \\
\hline Gender & $\begin{array}{l}71.859 \\
(11.582)^{* * *}\end{array}$ & $\begin{array}{l}3.502 \\
(7.269)^{* * *}\end{array}$ & $\begin{array}{l}0.869 \\
(9.081)^{* * *}\end{array}$ & $\begin{array}{l}366724.411 \\
(11.164)^{* * * *}\end{array}$ \\
\hline Household Size & $\begin{array}{l}12.820 \\
(3.907)^{* * *}\end{array}$ & $\begin{array}{l}2.912 \mathrm{E}-5 \\
(7.509)^{* * *}\end{array}$ & $\begin{array}{l}-0.049 \\
(-1.132)\end{array}$ & $\begin{array}{l}-30209.260 \\
(-2.017)^{*}\end{array}$ \\
\hline $\begin{array}{l}\text { Educational } \\
\text { Level }\end{array}$ & $\begin{array}{l}6.161 \\
(4.522)^{* * *}\end{array}$ & $\begin{array}{l}2.381 \mathrm{E}-5 \\
(2.355)^{* *}\end{array}$ & $\begin{array}{l}0.072 \\
(1.765)\end{array}$ & $\begin{array}{l}18328.718 \\
(3.313)^{* * * *}\end{array}$ \\
\hline $\begin{array}{l}\text { Years of } \\
\text { Experience }\end{array}$ & $\begin{array}{l}13.275 \\
(1.955)^{*}\end{array}$ & $\begin{array}{l}45.838 \\
(6.706)^{* * *}\end{array}$ & $\begin{array}{l}-0.004 \\
(-0.025)\end{array}$ & $\begin{array}{l}73347.367 \\
(2.492)^{* *}\end{array}$ \\
\hline $\begin{array}{l}\text { Extension } \\
\text { Services }\end{array}$ & $\begin{array}{l}1.854 \\
(0.014)\end{array}$ & $\begin{array}{l}16.804 \\
(2.472)^{* *}\end{array}$ & $\begin{array}{l}0.034 \\
(0.567)\end{array}$ & $\begin{array}{l}16277.388 \\
(0.795)\end{array}$ \\
\hline Sources of & $\begin{array}{l}-2.808 \\
(-0.354)\end{array}$ & $\begin{array}{l}3.054 \mathrm{E}-5 \\
(1998)^{*}\end{array}$ & $\begin{array}{l}0.037 \\
(1116)\end{array}$ & 1722.285 \\
\hline $\begin{array}{l}\text { Sources of } \\
\text { extension } \\
\text { Contacts }\end{array}$ & $\begin{array}{l}-0.174 \\
(-0137)\end{array}$ & $\begin{array}{l}4.494 \mathrm{E}-6 \\
(0.966)\end{array}$ & $\begin{array}{l}0.009 \\
(0.472)\end{array}$ & $\begin{array}{l}-3498.991 \\
(-0.512)\end{array}$ \\
\hline Access o Credit & $\begin{array}{l}13.356 \\
(6.154)^{* * * *}\end{array}$ & $\begin{array}{l}13.35 \mathrm{E}-2 \\
(2.876)^{* * * *}\end{array}$ & $\begin{array}{l}0.088 \\
(1.86)\end{array}$ & $\begin{array}{l}2245.980 \\
(1.480)\end{array}$ \\
\hline Access to & 27.678 & $3.463 \mathrm{E}-4$ & 0.034 & 4679.343 \\
\hline Training & $(2.257)^{* *}$ & $(1.865)$ & (0.908) & $(1.960)^{*}$ \\
\hline $\begin{array}{l}\text { Perception of } \\
\text { communication } \\
\text { network }\end{array}$ & $\begin{array}{l}1.456 \\
(0.003)\end{array}$ & $\begin{array}{l}-2.344 \mathrm{E}-4 \\
(-0.564)\end{array}$ & $\begin{array}{l}0.021 \\
(0.023)\end{array}$ & $\begin{array}{l}-1343.904 \\
(-1.432)\end{array}$ \\
\hline $\begin{array}{l}\text { Membership of } \\
\text { Cooperatives }\end{array}$ & $\begin{array}{l}12.678 \\
(2.257)^{* *}\end{array}$ & $\begin{array}{l}-0.004 \\
(-0.074)\end{array}$ & $\begin{array}{l}-0.342 \\
(-1.48)\end{array}$ & $\begin{array}{l}-2839.432 \\
(-2.323)^{* *}\end{array}$ \\
\hline Access to & 6.567 & $-5.433 \mathrm{E}-3$ & 1.24 & -1124.748 \\
\hline $\begin{array}{l}\text { Communication } \\
\text { network }\end{array}$ & $(3.089)_{* * *}$ & $(-0.332)$ & $(1.90)^{*}$ & $(-1.676)$ \\
\hline $\mathrm{R}^{2}$ & 0.927 & 0.784 & 0.390 & 0.590 \\
\hline Adjusted $\mathrm{R}^{2}$ & 0.898 & 0.728 & 0.276 & 0.577 \\
\hline F-value & 88.933 & 63.474 & 36.001 & 42.655 \\
\hline
\end{tabular}

${ }^{* * *}$ Significant at $1 \% ;{ }^{* *}$ Significant at $5 \% ;{ }^{*}$ Significant at $10 \%$

Result from Table 4 shows that the Linear functional form was the lead equation that best fit the model and it was used for further discussion. It has an $\mathrm{R}^{2}$ value of 0.927 . This implies that $92.7 \%$ of the frequency of access to information is explained by the independent variables
$\left(\mathrm{X}_{1}-\mathrm{X}_{13}\right)$ included in the model, while the remaining $7.3 \%$ is error of the non inclusion of some explanatory variables. The model has an f-value of 88.933 which is large and statistically significant at $1 \%$ level. This indicates that the explanatory variables adequately 
explained the dependent variable Y. Out of the thirteen independent variables Age, Gender, Household size, Educational level, Years of experience, Access to credit, Access to training, Membership of co-operations, and access to communication networks were found to be statistically significant and positively affect frequency of access to information. This implies that a unit increase in Age of respondents, difference in Gender, increase in household sizes, increase in Educational level, increase in years of experience, access to credit, access to training, increase participation in cooperative activities, and access to communication network, will lead to a successive increase in the frequency of access to information. This agrees with the findings of Rolls et al. (1999), who find that personal and institutional characteristics of the farmers were major factors influencing their access and search for information from different sources.

Table 5 revealed that the respondents perceived all the constraints under consideration to be important constraints in exception of poor marketing structure and poor road net works. This is a clear indication that the poultry farmers in the study area are facing serious and severe constraints hindering their potentialities, these constraints directly or indirectly limit their access to useful information and production resources. This finding is in line with that of Kursat et al. (2008), who reported that dairy farmers faced severe constraints, among which finance, poor infrastructural facilities and price instability were very critical.

Table 5: Distribution of Respondents According Constraints faced in Poultry production and their perception of the constraints

\begin{tabular}{|c|c|c|c|c|c|c|c|}
\hline \multicolumn{8}{|c|}{ Perception } \\
\hline Constraints & $\begin{array}{l}\text { Very } \\
\text { Important }\end{array}$ & Important & $\begin{array}{l}\text { Often } \\
\text { important }\end{array}$ & $\begin{array}{l}\text { Not } \\
\text { important }\end{array}$ & Sum & Mean & Remarks \\
\hline $\begin{array}{l}\text { Cost of accessing } \\
\text { information }\end{array}$ & $30(324.6)$ & $87(71.3)$ & $5(4.1)$ & - & 391 & 3.20 & Important \\
\hline $\begin{array}{l}\text { Poor } \\
\text { infrastructural } \\
\text { facilities }\end{array}$ & $98(80.3)$ & $15(12.3)$ & $9(7.4)$ & & 455 & 3.72 & Important \\
\hline $\begin{array}{l}\text { Poor market } \\
\text { structures }\end{array}$ & $14(11.5)$ & $2(1.6)$ & $88(72.1)$ & $18(14.8)$ & 256 & 2.09 & $\begin{array}{l}\text { Not } \\
\text { important }\end{array}$ \\
\hline Cultural beliefs & $83(68.0)$ & - & $39(32.0)$ & - & 410 & 3.36 & Important \\
\hline Illiteracy & $109(89.3)$ & $13(10.7)$ & - & - & 475 & 3.89 & Important \\
\hline $\begin{array}{l}\text { Unstable power } \\
\text { supply }\end{array}$ & $100(82.0)$ & $9(7.4)$ & 13(10.7) & - & 453 & 3.71 & Important \\
\hline $\begin{array}{l}\text { Poor } \\
\text { transportation }\end{array}$ & $1(0.8)$ & $1(0.8)$ & $94(77.0)$ & $26(21.3)$ & 221 & 1.81 & $\begin{array}{l}\text { Not } \\
\text { important }\end{array}$ \\
\hline Price instability & $18(14.8)$ & $87(71.3)$ & $3(2.5)$ & $14(11.5)$ & 353 & 2.89 & Important \\
\hline
\end{tabular}

*Figure in parenthesis are percentages 


\section{Conclusion}

From the findings of this study, it can be concluded that socio-economic and institutional variables significantly and positively influence poultry farmer's access to information and communication networks in the study areas, also poultry farmers were faced with serious constraints; these consequently affect their access to useful information and consequently their productivity.

\section{Recommendations}

Based on the findings of this study, the following recommendations are proffered:

1. Provision of infrastructural facilities by the government and other Nongovernmental organizations should be encouraged since the farmers perceive poor infrastructural facilities as a serious problem.

2. Dissemination of information through mass media especially through radio should be encouraged since the farmers perceive radio as an effective means of communication.

3. There should be favorable government policies in stabilizing the price of poultry products to encourage the farmers to produce more.

\section{References}

Adams, M.E. (1982). Agricultural Extension in Developing Countries. Intermediate Agricultural Series, Longman, U.K.

Adekunle, C.I. and Ogoto, J.U. (1994). Effective communication in sustainable agriculture technology transfer by the 21 st century in
Nigeria in Afolayan S.O et al (eds) issues and priorities for Nigeria agricultural in the twenty - first century. Proceedings of the inaugural conference of the agricultural extension society of Nigeria (AESON).

Adisa, O.B. and Akinkunmi, J.A. (2012). Assessing participating of Women in poultry production as a sustainable livelihood choice in Oyo State, Nigeria. International Journal of plant, Animal and Environmental Sciences, 2(2): 7382

Agwu, A.E.., Uche-mba, U.C. and Akinnabe, O. (2007). Use of information and communication technologies (ICTs) among researchers, extension workers and farmers in Abia and Enugu States. Implication for a National Agricultural Extension Policy on ICTs. Journal of Agricultural Extension 12(1): 37 - 39.

Branckaert, R.D.S. (2000). Avian influenza: The new challenge for family poultry. Guest Editorial, INFPD Newsletter 16(1): 1-3 available at http://www.fao.org/ag/againfo/them es/en/infpd/

FAO (2000). Improving Agricultural Extension. A reference manual. Natural and Resources Aquaculture extension guidelines for small scale farmers: based on experience, FAO Corporate Document Repository. pp1-5

Guèye, E.F. (2000). The role of family poultry in poverty alleviation, food security and the promotion of gender equality in rural Africa. 
Outlook on Agriculture, 29(2): 129136.

Kursat, D., Huseyin, E., Vadat, C., Savas, A. and O, Uysal (2008). Agricultural Information Systems and Communication Networks: A case of Dairy Farmers in the Samsun Province of Turkey. iRinformation Research 13(2): 1-6.

Ofuoku, A.U. (2010). "Influence Of Extension Agents' and Farmers' Communications Factors on the Effectiveness Poultry Technology Messages", Nigeria Tropical Agricultural Research \& Extension 15(1): 14-22.

Okoedo-Okojie, D.U. and Orhiakhi, H.O. (2012). "Perceived Communication Role of Agricultural Development Programme (ADP) Among Poultry Farmers in Southern Agricultural Zone of Edo State, Nigeria" Australian Journal of Basic and Applied Sciences, 6(13): 57-62.

Okonkwo, W.I. and Akubuo, C.O. (2001). Thermal analysis and evaluation of heat requirement of a passive solar energy poultry chick brooder in Nigeria. Journal of Renewal Energy, 9(1): 2-7.

Okunlola, J.O. and Olofinsawe, A. (2007). Effects of extension activities on Poultry Production in Ondo State, South Western Nigeria. Agricultural Journal, 2: 559-563.

Olaniyi, O.A. (2013). "Assessment of Utilization of Information and Communication Technologies (ICTs) among Poultry Farmers in
Nigeria: An Emerging Challenge" Transnational Journal of Science and Technology, 3(6): 11-15.

Roling, N. and Engel, P.G.H. (1991). The Development of Agricultural Knowledge Information System (SKIS) in Agricultural Extension: Worldwide Institutional Evolution and Forces for Change. Rivera, D. Gustafson (eds.) Elsevier Sci. Publ., Amsterdam, pp. 125-139.

Rolls, M.J., Slavik, M. and Miller, I. (1999). Information systems in Czech agriculture: sources and transfers of information for small and large scale farmers, new cooperatives and company farms. Rural Extension and Education research report no. 11. AEDD, The University of Reading, Reading.

Salau, E.S. and Saingbe, N.D. (2008). Access and Utilization of Information and Communication Technologies (ICTs) among Agricultural Researchers and Extension Workers in Selected Institutions in Nasarawa State, Nigeria. Production Agriculture and Technology (PAT) 4(2): 1-11 accessed on 23 April, 2015 from http//www.patnsukjournal.com

Waltham, N. (1999). Experiences in the management and exchange of electronic information for sustainable agriculture.

Livestock Research for Rural Development, 11(1): 1-4.

www.cipav.org.co//rrd/lrrd11/1/nick111. htm 